\title{
UPAYA PENINGKATAN HASIL BELAJAR MELALUI PENERAPAN MODEL PEMBELAJARAN RESIPROKAL DENGAN MEDIA BOLA CABANG OLAHRAGA PERMAINAN BOLA BASKET SISWA KELAS IX SEMESTER GANJIL SMP NEGERI 21 SURABAYA
}

\author{
Sumardi ${ }^{1}$ \\ ${ }^{1}$ FKIP Universitas PGRI Adi Buana Surabaya \\ Email: sumardi.ppi@gmail.com \\ Arif Djauhari $^{2}$ \\ ${ }^{2)}$ SMP Negeri 21 Surabaya \\ Email: arifdj2016@gmail.com
}

\begin{abstract}
Abstrak
Fokus masalah PTK ini adalah "Upaya Peningkatan Hasil Belajar Melalui Penerapan Model Pembelajaran Resiprokal Dengan Media Bola Cabang Olahraga Permainan Bola Basket Siswa Kelas IX Semester Ganjil SMP Negeri 21 Surabaya'. Rumusan masalah dalam penelitian ini adalah :Apakah dengan media bola dan model pembelajaran resiprokal/timbal balik dapat meningkatkan hasil belajar olahraga pada permainan bola basket, sehingga secara keseluruhan mampu mencapai Kriteria Ketuntasan Minimal (KKM). Penelitian tindakan kelas ini dilakukan bersamaan dengan program praktik dosen di sekolah Menengah Pertama Negeri 21 Surabaya. Sebelumnya didahului dengan observasi selama dua hari. Prosedur penelitiannya menggunakan perencanaan, pelaksanaa, evaluasi, dan refleksi. Teknik pengumpulan data dengan metode tes dan observasi, dan alat yang digunakan selama penelitian adalah media bola, lapangan, keranjang bola basket, lembar observasi. Teknik analisis data dengan rumus persentase. Hasil penelitian seperti berikut: Nilai rata-rata (Mean) semua di atas nilai KKM yaitu sebesar 70 dan nilai rata-rata sebesar 75,5. Hal ini menunjukkan bahwa siswa rata-rata dapat menguasai materi pembelajaran. Ada kendala akibat dari kebakaran AULA bulan Agustus 2018 di SMP Negeri 21. Kondisi pemerolehan hasil belajar pada Siklus I dapat dikatakan sudah bagus atau belum, maka perlu diadakan penelitian lagi dengan Siklus II. Pada Siklus II penelitian dimaksudkan untuk lebih memantapkan kondisi siswa khususnya tempat peneliti praktik. Hasil Siklus II, ternyataa hasil lebih bagus atau rata-ratanya naik menjadi 80,625 yang pada Siklus I rata-rata hanya 75,5 .
\end{abstract}

Keywords: resiprokal, media bola, dan permainan bola basket

\begin{abstract}
The focus of the PTK problem is "Efforts to Improve Learning Outcomes Through the Application of Media Reciprocal Learning Models with Ball Balls for the IX Class Semester Students of Basketball Games in the Middle School 21 Surabaya Middle School." The formulation of the problem in this study are: Is the ball media and reciprocal / reciprocal learning model able to improve sports learning outcomes in basketball games, so that overall able to achieve the Minimum Completion Criteria (KKM). This classroom action research was conducted in conjunction with the lecturer practice program at the Surabaya 21st Junior High School. Previously it was preceded by observation for two days. The research procedure uses planning, implementation, evaluation, and reflection. Data collection techniques with test and observation methods, and the tools used during the study were ball media, field, basket basket, observation sheet. Data analysis technique with percentage formula. The results of the study are as follows: Average values (Mean) are all above the $\mathrm{KKM}$ value which is equal to 70 and the average value is 75.5. This shows that the average student can master the learning material. There are obstacles due to the AULA fires in
\end{abstract}


August 2018 in SMP Negeri 21. The conditions for obtaining learning outcomes in Cycle I can be said to be good or not, so research needs to be done again with Cycle II. In Cycle II the study was intended to further strengthen the condition of students, especially the place of practice researchers. Cycle II results, it turns out the results are better or the average rises to 80,625 which in Cycle I is only 75.5 on average.

Keywords: reciprocity, ball media, and basketball games

\section{PENDAHULUAN}

Pembelajaran di sekolah menengah pertama memerlukan penangan yang sangat serius, karena secara umum dengan kasat mata anak usia SMP sekarang ini sudah banyak sekali melakukan berbagai penyimpangan sosial sehingga mengganggu optimalisasi hasil belajarnya. Peran guru di sini sangat sentral karena guru di samping mempunyai tugas mengajar artinya menyampaikan materi namun juga tidak kalah pentingnya yaitu mendidik anakanak generasi penerus. Dalam konteks mengajar seorang guru harus mempersiapkan segala sesuatunya, artinya bukan hanya semata-mata materi ajar saja tetapi guru sebagai pendidikan dalam mengajarpun juga dituntut selalu siap siaga dalam menangani berbagai hal yang muncul di sekolah, sehingga apapun yang terjadi di lingkungan kelas semua hendaknya bisa diatasi oleh pendidik itu sendiri. Mengajar merupakan proses dua dimensi, yaitu sebagai proses penyampaian materi pelajaran dan sebagai proses pengaturan lingkungan yang dapat merangsang siswa untuk belajar. Guru hendaknya memiliki kepiawaian dalam memotivasi siswanya untuk selalu belajar. Berkaitan masalah belajar menurut Suyono dan Hariyanto, (2011;24), bahwa "belajar sebagai suatu proses artinya proses konstruksi makna yang berlangsung terus menerus, setiap kali berhadapan dengan fenomena atau pengalaman baru. Proses belajarbukan kegiatan mengumpulkan fakta, melainkan lebih sebagai pengembangan pemikiran dengan membuat pengertian yang baru. Belajar bukanlah hasil perkembangan, melainkan perkembangan itu sendiri. Proses belajar yang sebenarnya terjadi pada waktu skema seseorang dalam keraguan (desonansi kognitif) yang merangsang pemikiran lebih lanjut. Situasi tidak keseimbangan (desekulibrium) adalah situasi yang baik untuk memacu belajar". Berkenaan dengan hal ini Wina Sanjaya (2007:44) mengemukakan bahwa : mengajar bukanlah hanya sekedar menyampaikan materi pelajaran saja, akan tetapi merupakan suatu pekerjaan yang bertujuan dan bersifat kompleks dan profesional sehingga sangat dibutuhkan adanya keterampilan khusus atau suatu keilmuan tertentu yang sifatnya sangat spesifik dan hal ini sangat diperlukan waktu yang relatif lama. Mengajar di sini bukanlah menggunakan suatu keputusan atas dasar pertimbangan sekehendak dirinya yang sangat subjektif, namun mengajar di sini didasarkan atas pertimbanganpertimbangan tertentu berdasarkan keilmuan tertentu yang menjadi spesialisasinya sehingga mengajar di sini sebagai pekerjaan yang sifatnya sangat profesional. Oleh karena itu untuk menjadi seorang guru disesuaikan dengan latar belakang pendidikan keguruan yang memadai, artinya guru bukan sekedar mengandalkan strategi mengajar namun harus memperhatikan isi atau materi, atau paling tidak pernah mendalami secara otodidak.

Model pembelajaran yang 
penulis

lakukan

adalah

resiprokal/timbal balik. Ada beberapa langkah yang ditempuh diantaranya :

a. Guru mengatur siswa agar berpasangpasangan.

b. Guru membagikan bahan ajar, yang berisi deskripsi tangan dan indikator tugas gerak kepada siswa.

c. Siswa mempelajari tugas gerak dan indikator keberhasilannya.

d. Siswa melaksanakan tugas gerak, dan bergantian dan bilamana pelaku sudah berhasil menampilkan gerak sesuai indikator yang telah ditentukan.

e. Guru memberikan kesimpulan secara umum.

f. Evaluasi.

Namun kondisi seperti ini tidak terjadi di SMP Negeri 21 Surabaya, semua pendidik di SMP Negeri 21 Surabaya sudah berlatar belakang minimal Strata satu (S1).Kondisi yang ada di SMP Negeri 21 Surabaya, menurut pengamatan saya selaku dosen yang sedang melaksanakan PDS (Praktik Dosen di Sekolah) memang terlihat dengan jelas bahwa kondisi di SMP Negeri 21 Surabaya masih perlu perbaikan sarana dan prasarana. Keseharian yang sering nampak di sini setiap ada pembelajaran praktik nampak sekali belum ada lapangan sepak bola, belum lapangan bola basket secara memadai, karena bagaimanapun juga perlengkapan sarana dan prasarana yang bisa menunjang pelaksanaan dalam pembelajaran seharusnya wajib dipenuhi. Mengingat sarana dan prasarana ini termasuk bagian dari kurikulum yang mana semua yang diperlukan dalam kurikulum wajib dipenuhi. Berkaitan dengan masalah sarana dan prasarana beikut ini saya kutipkan dari kementerian sebagai berikut:
Mengajar mempunyai makna transfer of knowlege yaitu memindahkan ilmu dari guru ke siswa yang dilakukan secara sengaja dengan berbagai proses yang dilakukannya. Berkenaan dengan hal ini Wina Sanjaya (2007;40) mengemukakan bahwa, mengajar bukanlah hanya sekedar menyampaikan materi pelajaran saja, akan tetapi merupakan suatu pekerjaan yang bertujuan dan bersifat kompleks dan profesional sehingga sangat dibutuhkan adanya keterampilan khusus atau suatu keilmuan tertentu yang sifatnya sangat spesifik dan hal ini sangat diperlukan waktu yang relatif lama. Mengajar di sini bukanlah menggunakan suatu keputusan atas dasar pertimbangan sekehendak dirinya yang sangat subjektif, namun mengajar di sini didasarkan atas pertimbanganpertimbangan tertentu berdasarkan keilmuan tertentu yang menjadi spesialisasinya sehingga mengajar di sini sebagai pekerjaan yang sifatnya sangat profesional. Oleh karena itu untuk menjadi seorang guru disesuaikan dengan latar belakang pendidikan keguruan yang memadai, artinya guru buka sekedar mengandalkan strategi mengajar namun harus memperhatikan isi atau materi. Menurut Wina Sanjaya (2008:46) faktor-faktor yang berpengaruh terhadap sistem pembelajaran adalah:

a. Faktor Guru

$\begin{array}{lcr}\text { Guru adalah komponen } & \begin{array}{r}\text { yang } \\ \text { sangat }\end{array} \text { menentukan } & \text { dalam } \\ \text { implementasi suatu } & \text { strategi } \\ \text { pembelajaran. } & \text { Tanpa } & \text { guru, }\end{array}$ bagaimanapun bagus dan idealnya suatu strategi, maka strategi itu tidak mungkin bisa diaplikasikan. Layaknya seorang prajurit di medan pertempuran. Keberhasilan penerapan strategi berperang untuk menghancurkan musuh akan sangat bergantung kepada kualitas prajurit 
itu sendiri. Demikian juga dengan guru. Keberhasilan implementasi suatu strategi pembelajaran akan tergantung pada kepiawaian guru dalam menggunakan berbagai metode, teknik dan taktik dalam pembelajaran.

b. Faktor Siswa

Siswa adalah organisme yang unik yang berkembang sesuai dengan tahap perkembangannya. Perkembangan anak adalah perkembangan seluruh aspek kepribadiannya, akan tetapi tempo dan irama perkembangan masingmasing anak pada setiap aspek tidak selalu sama. Proses pembelajaran dapat dipengaruhi oleh perkembangan anak yang tidak sama itu, di samping karakteristik lain yang melekat pada diri anak.

c. Faktor Sarana dan Prasarana

Sarana adalah segala sesuatu yang mendukung secara langsung terhadap kelancaran proses pembelajaran, misalnya media pembelajaran, alatalat pelajaran, perlengkapan sekolah, dan lain sebagainya, sedangkan prasarana adalah segala sesuatu yang secara tidak langsung dapat mendukung keberhasilan proses pembelajaran, misalnya jalan menuju sekolah, penerangan sekolah, kamar kecil, dan lain sebagainya. Kelengkapan sarana dan prasarana akan menuntun guru dalam menyelenggarakan proses pembelajaran, dengan memiliki sarana dan prasarana merupakan komponen penting yang dapat mempengaruhi proses pembelajaran.

d. Faktor Lingkungan

Dilihat dari dimensi lingkungan ada dua factor yang mempengaruhi proses pembelajaran, yaitu factor organisasi kelas dan factor iklim social- psikologi. Faktor organDisasi kelas yang di dalamnya meliputi jumlah siswa dalam satu kelas merupakan aspek penting yang bisa mempengaruhi proses pembelajaran.

Guru dalam proses pembelajaran memengang peranan yang sangat penting. Peran guru, untuk siswa pada usia pendidikan dasar, karena guru pada tingkat pendidikan dasar tidak mungkin dapat digantikan oleh perangkat lain, seperti Televisi, Radio, Komputer dan lain sebagainya. Begitu juga halnya dengan siswa sebuah organisme yang sedang berkembang yang memerlukan bimbingan dan bantuan orang dewasa. Jadi proses pembelajaran guru dengan siswa adalah faktor utama dalam menentukan keberhasilan belajar. Dengan demikian efektivitas proses pembelajaran terletak di pundak guru. Jadi bagaimanapun juga guru masih tetap merupakan orang seorang yang dianggap sebagai penentu, sehingg guru sebagai pendidikan harus mencerminkan sebagai public figure. Artinya orang seorang yang tetap menjadi panutan, sehingga seorang guru tidak boleh memiliki ilmu yang minimalis. Model pembelajaran yang penulis lakukan adalah resiprokal/timbal balik. Ada beberapa langkah yang ditempuh diantaranya :

a. Guru mengatu

r siswa

agar

berpasa

ng-

pasanga

n.

b. Guru membagikan bahan ajar, yang berisi deskripsi tangan dan indikator tugas gerak kepada siswa.

c. Siswa mempelajari tugas gerak dan 
indikator

keberhasilannya.

d. Siswa melaksanakan tugas gerak, dan bergantian dan bilamana pelaku sudah berhasil menampilkan gerak sesuai indikator yang telah ditentukan.

e. Guru

memb

erikan

kesim

pulan

secara

umum

f. Evalu

asi.

Dalam Peraturan Menteri

Pendidikan Nasional Republik

Indonesia yang berkaitan dengan

Standar Sarana dan Prasarana.Peraturan

Menteri Pendidikan Nasional Republik

Indonesia No 24 Tahun 2007 tentang

Standar Sarana dan Prasarana untuk

Sekolah Dasar/Madrasah Ibtidaiyah

(SD/MI), Sekolah Menengah

Pertama/Madrasah Tsanawiyah

(SMP/MTs), dan Sekolah Menengah Atas/Madrasah

Aliyah

(SMA/MA).Peraturan

Menteri

Pendidikan Nasional Republik

Indonesia No 40 Tahun 2008 tentang

Standar Sarana Prasarana untuk

Sekolah Menengah Kejuruan (SMK)

dan Madrasah Aliyah Kejuruan (MAK).

Peraturan Menteri Pendidikan Nasional

Republik Indonesia Nomor 33 Tahun 2008 tentang Standar Sarana Prasarana untuk Sekolah Luar Biasa. Mengingat pentingnya masalah sarana dan prasarana di sekolah, maka kondisi semacam ini akan dimanfaatkan sebagai kebutuhan yang dikaitkan dengan ajang akreditasi sekolah. Sarana adalah sesuatu yang mendukung secara langsung terhadap kelancaran proses pembelajaran, media pembelajaran, alat- alat pelajaran, perlengkapan sekolah dan sebagainya. Selaras dengan itu pembelajaran pelajaran pendidikan jasmani, olahraga dan kesehatan (Penjasorkes) SMP, di mana siswa dituntut harus mampu menguasai 3 Aspek domain yaitu Aspek Psikomotorik,

Aspek Kognitif dan Aspek Afektif. Untuk mencapai ketiga Aspek ini guru sudah seharusnya mencari dan menentukan model, teknik, media pendukung, karena salah satu keputusan yang paling penting dalam merancang pembelajaran ialah dengan menggunakan media yang sesuai dalam rangka penyampaian pesan-pesan pembelajaran Dick dan Carey (Dalam Lamudji, 2005). Menciptakan Proses Pembelajaran praktik tidaklah mudah mencapai ketuntasan mengingat waktu yang tersedia sangatlah terbatas sehingga Penelititan Tindakan Kelas ini sangatlah tepat untuk mencari upaya penyelesaian permasalahan siswa. Dengan adanya model pembelajaran, media bola asli diharapkan dapat lebih membangkitkan aktivitas praktik dan kompetensi sesuai yang diharapkan. Seperti pembelajaran atletik merupakan salah satu materi penjasorkes di sekolah menengah pertama (SMP). Pendidikan Penjasorkes dirancang melalui aktivitas jasmani yang didesain untuk meningkatkan kebugaran jasmani siswa, mengembangkan keterampilan motorik, pengetahuan dan perilaku hidup sehat, aktif dan sportif, salah satunya Nnmor cabang olahraga permainan bola basket pada kurikulum 2013 (K-13) SMP terdapat pada standar kompetensi pertama yaitu mempraktikkan berbagai teknik dasar permainan dan olahraga serta nilai- nilai yang terkandung di dalamnya. Adapun indikatornya siswa dituntut untuk mampu melakukan teknik dasar permainan bola kasket. Dan untuk bisa menguasai hal tersebut tentu 
sekolah sebagai lembaga pendidikan yang membelajarkan para peserta didik dituntut selalu melengkapi semua sarana dan prasarana yang dipandang masing kurang atau sebagian alat yang dinilai sudah waktunya diperbaiki bahkan bila perlu diganti. Dalam kegiatan pratik di samping juga sebagai ajang penelitian di sekolah juga bisa dimanfaatkan sebagai ajang pengabdian kepada masyarakat sekolah, karena yang namanya masyarakat tidak terbatas hanya pada masyarakat umum seperti di pedesaan atau di perkotaan namun juga termasuk masyarakat yang telah terorganisasi secara rapi bagus seperti contohnya lembaga pendidikan persekolahan. Terkait dengan masalah ini, maka peneliti memanfaatkan peluang untuk ikut membangun/memperbaiki mutu pendidikan di tingkat sekolah menengah pertama melalui observasi yang dilanjut melakukan praktik langsung bahkan bisa juga dilakukan kegiatan penelitian tindakan kelas (PTK). Berdasar hasil pengamatan di lapangan, maka peneliti yang sekaligus sebagai peserta PDS merasa perlu melakukan kegiatan yang terkait meningkatkan hasil belajar siswa khususnya yang terkait dengan pembelajaran praktik pendidikan jasmani dan kesehatan olahraga sangat perlu ditangani secara serius, karena membelajarkan peserta didik tentang praktik di lapangan tidak mudah. Sebagai mana kita ketahui bersama, untuk melakukan olahraga praktik tidak mudah seperti yang dibayangkan, karena tanpa ada proses sistematis ini malah akan membahayakan bagi siswa (cidera). Pelajaran olahraga merupakan pelajaran yang sangat disenangi oleh siswa, tetapi berbeda halnya dengan cabang olahraga permainan bola basket justru siswa sangat sulit untuk melakukan, alasan yang sering terdengar dominan melakukan gerakan yang diawali dengan lari dan lompatan yang menguras tenaga serta sangat melelahkan. Oleh karena itu peneliti mencoba memodifikasi sistem pembelajaran cabang olahraga permainan bola basket ini kedalam bentuk bermain menggunakan media bola, dengan tujuan mengembangkan teknik dasar yaitu perbedaharaan gerak dasar. Gerak dasar anak apabila sesering mungkin dilakukan maka dia akan semakin berkembang dan lambat laun gerak inilah yang nantinya akan mampu menciptakan gerak yang diharapkan. Dengan gerakan yang sederhana, tidak terlalu terstruktur dan disesuaikan dengan tingkat kemampuan serta karakteristik anak (Soepartono, 2004). Untuk menunjang pencapaian tujuan sesuai yang diharapkan, maka dipandang perlu dilakukan perubahan-perubahan misalnya untuk meningkatkan hasil belajar perlu dilakukan mendesain bola sebagai media yang digunakan dalam pembelajaran praktik di lapangan maupun di dalam kelas. Media bola merupakan media yang sangat mudah untuk dijumpai ditengah-tengah masyarakat terlebih media bola yang dimofikasi ini sering sekali masyarakat membuangnya. Kelebihan media ini jika saat digunakan bila terkena atau tersentuh dengan fisik siswa tidak akan mendatangkan resiko. Media bola ini sangat menyenangkan bagi semua siswa yang ingin menggunakannya. Berdasar berbagai uraian di atas, akhirnya penulis melakukan penelitian tidakan kelas dengan judul seperti berikut: "Upaya Peningkatan Hasil Belajar Melalui Penerapan Model Pembelajaran Resiprokal Dengan Media Bola Cabang Olahraga Permainan Bola Basket Siswa Kelas IX Semester Ganjil SMP Negeri 21 Surabaya".

\section{METODE PENELITIAN}

Penelitian tindakan kelas ini dilakukan 
atas dasar pengalaman peneliti di mana selama hampir kurang labih 3 bulan mulai Agustus 2018 sampai dengan Oktober 2018 dengan efektif penelitian selama 3 minggu pelaksanakan Praktik Dosen di Sekolah Menengah Pertama Negeri 21 Surabaya, maka peneliti menemukan beberapa hal di lapangan seperti siswa sebagian kurang tertarik melakukan praktik permainan bola besar (bola basket) terutama para siswi. Hal ini sebelum peneliti melaksanakan praktik dosen di sekolah selama 2 hari peneliti melakukan observasi tentang pola pembelajaran di SMP Negeri 21 Surabaya. Metode yang digunakan dalam penelitian tindakan kelas (PTK) ini adalah metode yang mengutamakan pada observasi baik observasi di lapangan olahraga maupun observasi dalam kelas pada saat pembelajaran sedang berlangsung, di mana observasi dilakukan secara bergantian antara dosen yang sedang melaksanakan praktik di sekolah bekerja sama dengan guru mitra sekolahan tersebut. Metode ini digunakan untuk bisa mendeskripsikan kondisi sekolah yang sebenarnya, karena walaupun hanya dengan observasi secara nyata, maka pendeskripsian ini sudah bisa dilakukan sesuai data yang ada. Setiap pelajaran/praktik olahraga khususnya pada permainan bola basket peneliti jumpai lebih dari $30 \%$ siswi tidak antusia/semangat dalam mengikuti pelajaran praktik. Kemungkinan sekali hal ini terjadi karena berbagai faktor utama adalah tempat praktik siswa sarana dan prasarana sangat kurang.

\section{HASIL DAN PEMBAHASAN PENELITIAN}

Sebagai dosen yang sedang melakukan praktik di sekolahan tersebut kurang bijak apabila terlalu kedalam dalam melakukan penilaian. Penilaian yang sifatnya kurang peneliti lakukan masih dalam batas manusiawi. Dalam melaksanakan penelitian tindakan kelas penelitian juga menggunakan model siklus yang terdiri dari dua siklus. Hasilnya siklus satu cukup bagus artinya semuanya berada di atas KKM (70). Pada siklus pertama terdapat nilai 70 hanya 3 siswa sedang pada siklus kedua minimal memperoleh nilai $75 \mathrm{ke}$ atas. Jika dilihat dari hasil nilai rata-rata (M) pada siklus pertama sebesar 75,7 sedangan pada siklus kedua nilai rataratanya agak lebih tinggi, yaitu sebesar 80,625 , artinya ada peningkatan yang cukup besar yaitu sebesar 4,93 jika dihitung setiap individu naik kurang lebih 30\%. Ini berasal dari jumlah selisih kenaikan dibagi jumlah subjek yaitu 16 siswa. Pada artikel bola basket ini, penulis juga akan ulas mengenai teknik dasar permainan bola basket. Adapun teknik dasar tersebut meliputi dribble, passing, pivot, shooting, dan rebound. Teknik menggiring (dribble) bertujuan untuk mengumpannya pada kawan satu tim yang berdekatan dengan ring lawan ataupun membawa bola menghindari lawan. Dribble pada bola basket dilakukan dengan memantulkan bola di permukaan lantai menggunakan tangan. Ada dua jenis dribble pada olahraga bola basket, yakni dribble tinggi dan dribble rendah. Dribble tinggi ialah teknik memasuki wilayah pertahanan lawan dengan menggiring bola secara cepat. Teknik ini dilakukan dengan berjalan cepat ataupun berlari saat pemain yang memegang bola berada jauh dari pemain lawan. Sementara dribble rendah ialah teknik dribble untuk mempertahankan bola basket dari sergapan tim lawan. Teknik ini digunakan saat mencari celah ketika lawan sedang lengah. Gerakan dalam permainan olahraga bola basket memang begitu kompleks. Adapun gerakan dalam olahraga bola basket meliputi gabungan dari jalan, lari, 
lompat, dan unsur kekuatan, kecepatan, kelenturan, ketepatan, daya tahan, dan masih banyak lainnya. Dalam permainan bola basket terdapat beberapa peraturan dasar yang perlu ditaati. Adapun peraturan dasar permainan bola basket meliputi pemain bisa melemparkan bola dari segala arah dengan salah satu atau kedua tangan, pemain bisa memukul bola ke segala arah namun tak boleh menggunakan kepalan tangan, pemain tidak boleh berlari sembari memegang bola. Bola harus dilemparkan pada titik pemain menerima bola, bola harus dipegang secara baik di dalam maupun di antara telapak tangan, serta pemain tak diperbolehkan untuk menjegal pemain lawan dengan cara apapun. Tindakan menjegal lawan bisa dikenai sanksi pelanggaran. Tak hanya itu, jika salah satu pemain melakukan kesalahan sebanyak tiga kali secara berturut-turut, maka kesalahan itu akan dihitung poin untuk lawan. Jikalau lemparan bola basket masuk ke keranjang, maka memperoleh nilai. Apabila bola terlempar keluar dari arena pertandingan, maka yang memiliki hak untuk memainkannya pertama kali ialah pemain pertama yang menyentuhnya. Empat sesi ialah waktu permainan, di mana masing-masing memiliki durasi selama sepuluh menit.

Untuk selanjutnya bagi Tim yang berhasil memasukkan bola ke ring dengan jumlah poin terbanyak, maka tim tersebut dinyatakan sebagai pemenang. Selanjutnya, teknik mengumpan (passing). Teknik ini dilakukan untuk mengarahkan bola kepada rekan satu tim. Ada enam jenis passing dalam permainan bola basket, yakni:

1. overhead passing (melempar bola dari atas kepala)

2. chest pass (melempar bola di depan dada dengan dua tangan)

3. baseball pass (mirip dengan gerakan melempar bola pada permainan

4. baseball)

5. hook pass (dilakukan dengan posisi melipat di atas bahu)

6. under pas (mengumpan dari arah pinggang)

7. bounce pass (memantulkan bola ke bawah agar diterima rekan satu tim).

Ada juga teknik pivot, di mana berupa teknik menipu tim lawan. Nantinya pemain menggerakkan badan dengan kedua tangan menjaga bola dari serbuan lawan serta bertumpu pada salah satu kaki. Sementara teknik menembak (shooting) ialah teknik memasukkan bola ke dalam ring lawan dengan teknik set shoot (diam di tempat serta memasukkan bola dengan satu atau dua tangan), lay up (memasukkan bola dengan berlari kemudian melompat), serta jump shoot (memasukkan bola dengan melompat). Lain halnya dengan teknik rebound, di mana dengan mengambil bola yang gagal masuk ke ring. Adapun jenis rebound ialah rebound ofensif dan defensif olahraga bola basket adalah suatu permainan yang gerakannya sangat kompleks, yaitu gabungan dari lempar, tangkap, jalan, lari, lompat serta unsur kekuatan, kecepatan, ketepatan, daya tahan, kelentukan, dan lain-lain (Suherman, 2018:44).

Untuk dapat mencapai sesuai yang diharapkan, maka pertama-tama yang harus dimiliki ialah: 1) memiliki gerak dasar melalui permainan bola basket, 2) memiliki pengetahuan tentang gerak dasar permainan bola basket, 3) Permainan yang sesuai dan dapat memberi pengalaman belajar untuk menggunakan dan beradaptasi dengan gerakan motorik, menggunakannya pada situasi permainan yang serba berubahubah, dan 4) Memiliki sikap sportivitas, kerja sama, tanggung jawab, dan disiplin dan dapat memahami budaya orang lain. 
Gerakan dasar yang harus dikuasai/dimiliki oleh setiap pemain bola besar (bola basket) ialah:

1. Gerakan melempar dan menangkap bola,

2. Gerakan menggiring bola,

3. Gerakan menembak,

4. Gerakan-gerakan berporos,

5. Gerakan Lay Up Shoot, dan

6. Gerakan merebur bola/rebound. (Ahmadi, 2007)

\section{KESIMPULAN}

Dalam melaksanakan penelitian tindakan kelas penelitian juga menggunakan model siklus yang terdiri dari dua siklus. Hasilnya siklus satu cukup bagus artinya semuanya berada di atas KKM (70). Pada siklus pertama terdapat nilai 70 hanya 3 siswa sedang pada siklus kedua minimal memperoleh nilai $75 \mathrm{ke}$ atas. Jika dilihat dari hasil nilai rata-rata (M) pada siklus pertama sebesar 75,7 sedangan pada siklus kedua nilai rata-ratanya agak lebih tinggi, yaitu sebesar 80,625, artinya ada peningkatan yang cukup besar yaitu sebesar 4,93 jika dihitung setiap individu naik kurang lebih $30 \%$. Ini berasal dari jumlah selisih kenaikan dibagi jumlah subjek yaitu 16 siswa. Artinya bahwa dalam penelitian ini ada peningkatan hasil belajar melalui penerapan model pembelajaran resiprokal dengan media bola cabang olahraga permainan bola basket siswa kelas IX semester ganjil SMP Negeri 21 Surabaya.

Hasil tersebut secara deskriptif menunjukkan bawah, untuk dapat mencapai permainan bola basket sesuai yang diharapkan, maka pertama-tama yang harus dimiliki siswa adalah 1) memiliki gerak dasar melalui permainan bola basket, 2) memiliki pengetahuan tentang gerak dasar permainan bola basket, 3) Permainan yang sesuai dan dapat memberi pengalaman belajar untuk menggunakan dan beradaptasi dengan gerakan motorik, menggunakannya pada situasi permainan yang serba berubahubah, dan 4) Memiliki sikap sportivitas, kerja sama, tanggung jawab, dan disiplin dan dapat memahami budaya orang lain. Gerakan dasar yang harus dikuasai/dimiliki oleh setiap siswa dalam permainan bola baske seperti yang dikatakan Ahmadi (2007:17) diantaranya adalah gerakan melempar dan menangkap bola basket yang meliputi; gerakan menggiring bola, gerakan menembak, gerakan-gerakan berporos, gerakan lay up shoot, dan gerakan merebur bola/rebound. (Ahmadi, 2007).

\section{DAFTAR PUSTAKA}

Depdiknas.(2003)Undang Undang RI Nomor 20 tahun 2003 Tentang Sistem Pendidikan Nasional. Jakarta.

Depdiknas. (2005) UU RI Nomor 14 tahun 2005 tentang Guru dan Dosen. Jakarta.

Depdiknas. (2007) Permendiknas Nomor 41 tahun 2007 tentang Standar Proses. Jakarta.

Depdiknas.

Permendiknas 2006

tentang SI dan SKL dilengkapi PP RI No 19 Tahun 2005 tentangStandar Nasional Pendidikan. Jakarta:Sinar Grafika.

Dian Marisanita Sari (2009) Penerapan Strategi Think Talk Write (Ttw) Dalam Pembelajaran Bahasa sunda Ditinjau Dari Minat Belajar Siswa. Surakarta: FKIP Universitas Muhamadiyah (Skripsi).

Fitriyyah, Nurul. (2011). Penerapan Strategi Think Talk Write (TTW) Dalam Pembelajaran Bahasa sunda Untuk Meningkatkan 
Kemampuan Pemecahan Masalah

Bahasa sunda Siswa

SLTP.Bandung: FPMIPA UPI (Skripsi).

Hanafiah, dkk. (2010) . Konsep Dasar Penelitian Tindakan Kelas dan Model-Model Pembelajaran. Bandung: FKIP UNINUS.

ISBN . (2009). Peraturan Pemerintah R.I. Nomor 74 tahun 2008 tentang guru. Jakarta: BP. Cipta Jaya.

Isjoni . (2009). Cooperative Learning (Efektifitas pembelajaran kelompok). Bandung: Alfabeta.

Kunandar. (2008) Langkah Mudah Penelitian Tindakan Kelas sebagai Pengembangan Profesi Guru. Jakarta: PT Raja Grafindo Persada.

Mulyasa, E. (2009). Menjadi Guru Profesional Menciptakan Pembelajaran Kreatif dan Menyenangkan. Bandung : PT Remaja Rosdakarya.

Lie, Anita. (2008). Cooperative Learning (Mempraktikkan Cooperative Learning di ruangruang kelas). Jakarta : Grasindo.

Suyono dan Hariyanto, (2012). Belajar dan Pembelajaran. Bandung: PT Remaja Rosdakarya

Wina Sanjaya, (2007). Strategi Pembelajaran. Jakarta: Kencana Prenada Media Group

Zaenal Arifin, 2012. Metodologi Penelitian Pendidikan. Surabaya: Lentera Cendikia. 
